\title{
Karadeniz’in Bölgesel Güvenlik Kompleksi olarak İncelenmesi
}

\author{
Pınar AKGÜL \\ Giresun Üniversitesi, İİB, Uluslararası İlişkiler Bölümü \\ pinar.akgul@giresun.edu.tr \\ ORCID ID: https://orcid.org/0000-0001-8184-3103
}

\begin{tabular}{lrr} 
Araştırma Makalesi & DOI: $10.31592 /$ aeusbed.607455 \\
\hline Geliş Tarihi: 20.08 .2019 & Revize Tarihi: 02.07 .2020 & Kabul Tarihi: 02.07.2020
\end{tabular}

\section{Atıf Bilgisi}

Akgül, P. (2020). Karadeniz'in bölgesel güvenlik kompleksi olarak incelenmesi. Ahi Evran Üniversitesi Sosyal Bilimler Enstitüsü Dergisi, 6(2), 550-569.

ÖZ

Soğuk Savaşın bitimiyle Karadeniz bölgesi, konu olarak, gelişen uluslararası ilişkiler kavramları bakımından önemli hale gelmiştir. Bu bağlamda klasik bir güvenlik/politik değerlendirmenin bölgeyi ele almada yetersiz olduğu, ancak farklı kavramların iç içe olduğu eklektik bir yapı gereksinimi ortaya çıkmıştır. Çünkü kavramsal olarak hem güvenlik kavramı hem de yapı/aktör görüşü değişmiştir. Bu değișiklikleri göz önünde bulunduran"bölgeselcilik" ve"bölgesel güvenlik kompleksi" kavramlarından ilham alan bu çalı̧ma Karadeniz'i incelemiştir. İki kavramın seçilmesinin nedeni kavramların bölgeyi yeni bir aktör olarak ele alması ve bölgeyi küresel aktörler ve devletler gibi önemli kabul etmesi ve de güvenliği klasik askeri güvenlik algısından çıkartıp yanı sıra politik, ekonomik, çevre ve toplumsal güvenliği de göz önüne almalarıdır. Bu durum bölge çalışmalarının içeriğini ve kapsamını da zenginleştirmiştir. İlk olarak, bölge ülkelerinin ulusal güvenlik hassasiyetlerinin irdelendiği çalışmada devamında örgütsel yapılanmalar ortaya konarak bölgesel güvenlik kompleksi olușturabilecek tehditler incelenmiștir. Bu bağlamda Karadeniz'in, bazı istisnaları göz önünde bulundurularak, hem bölge olarak kabul edilebileceği hem de bölgesel güvenlik kompleksi oluşturabilecek potansiyele sahip olduğu savunulmuştur. Bu durum Karadeniz'i çatışmanın ve işbirliğinin bir arada olduğu sui generis bir bölge ve bölgesel güvenlik kompleksi olarak ortaya çıkarmaktadır.

Anahtar kelimeler:Karadeniz, bölgeselleşme, bölgesel güvenlik kompleksi teorisi.

\section{The Analysis of the Black Sea as a Regional Security Complex}

\begin{abstract}
The Black Sea Region, as a subject, becomes important in developing International Relations concepts after the end of the Cold War. In the context of this issue, it emerges that classical security/political theories are insufficient to address the region but needs an eclectic framework including different concepts. This is because conceptually both the concept of security and the notion of agent/actor changed dramatically. Taking into account these changes, this article is inspired from concepts of "regionalism" and "regional security complex" in scrutinising the Black Sea. Reasons behind selecting these concepts are to consider regions as news actors and accepting them as important as global actors and states, and also apart from classical military security, broadening a security approach to taking into account political, economic, environment and societal sectors. This enriches the content and scope of region studies. Initially, this article scrutinises national security vulnerabilities of each countries of the region and continues with regional organisations and within this context potential threats that might paves the way for the formation of regional security complex are examined. In the context of this issue, it is argued that the Black Sea, despite exceptions, can be accepted as a region and has a potential to form a regional security complex. Thus, this situation reveals that the Black Sea is a sui generis region and a regional security complex including both conflict and cooperation.
\end{abstract}

Keywords: Black Sea, regionalism, regional security complex theory.

\section{Giriş}

Tarih boyunca etrafinı çevreleyen imparatorlukların güç mücadelesinin odağında olan Karadeniz bölgesi; Soğuk Savaş dönemine Türkiye ve Yunanistan'ın yer aldığı Batı Bloğu ve diğer bölge ülkelerinin yer aldığı Sovyet Bloğu arasında sıkışmıştır. Bu durum farklı öncelikleri olan blokların ortak bir payda altında ilişkilerini geliştirmelerini engellemiş, aksine tarafların bir diğerini güvenlik açısından tehdit olarak görmeleri sonucunu doğurmuştur. Bu da Karadeniz'in daha ziyade havza ve kapalı deniz olarak anılmasına neden olmuştur (Aybak, 2001). Karadeniz, Ruslar açısından sıcak denizlere inmek için önemli geçit, Türkler için ise bir göl ve Rusların sıcak denizlere inmesini engelleyen set olarak görünmekteydi (Aybak, 2001). Bu farklı algılar Soğuk Savaşın bitimiyle yerini hem küresel hem de bölgesel olarak yeniden değerlendirilmeye ve yeni arayışlara bırakmıştır. Bölge 
bu manada iki farklı unsur sunmaktadır. Soğuk Savaşın bitimiyle bölgede yeni çatışma alanlarının ortaya çıkması ve bağımsızlıklarını yeni kazanan ülkelerin siyasi ve ekonomik bunalımları dezavantaj oluştururken; özellikle bölgenin jeopolitik konumu - zengin enerji kaynaklarına yakın olması (Hazar havzas1, Orta Doğu gibi) ve bu kaynaklara sahip olmas1 (Azerbaycan ve Rusya gibi), ve de ticari ilişkilerin gelişmesiyle yeni Pazar olasılığı sunması açısından - bölgeye olan ilgiyi hem stratejik hem de politik açılardan daha da arttırmıştır.

$\mathrm{Bu}$ yeni durumu onun literatürde yer bulmasını sağlamıştır. Mevcut literatürde Karadeniz ile ilgili çalışmalar çoğunlukla alanın bir bölge olup olmadı̆̆ 1 tartışmaları üzerinde kuruludur. Bunda özellikle bölgeselcilik kavramının kapsamının geniş olmasının da payı olmaktadır. Soderbaum'un (2016) da belirttiği gibi bölge kavramı farklı insanlar tarafından farklı zamanda farklı biçimlerde anlaşılmaktadır. Bölgeselcilik kavramı eski ve yeni bölgeselcilik olmak üzere ikiye ayrılmakta ve her iki terim de farklı içerikler sunmaktadır. Özellikle Soğuk Savaşın bitimiyle uluslararası sistem dramatik bir şekilde değişmiştir. Bu da bölgelerin öneminin daha da ortaya çıkmasını sağlamıştır. Ayrımı özetlemek gerekirse eski bölgeselcilik Soğuk Savaşın iki kutuplu yapısında ortaya çıkarken, yeni bölgeselcilik çok kutuplu ve küreselleşmiş bir düzende oluşmuştur. Eski bölgeselcilik daha ziyade coğrafi, ortak kimlik ve kültürel ve tarihsel bağ ortaya koysa da yeni bölgeselcilik bunları reddetmektedir. Son olarak eski bölgeselcilik komşu ülkelerin oluşturduğu gruplarla ilgilenirken, yeni bölgeselcilik hem devletler hem de devlet-dışı aktörlerle ilgilenmektedir (Hettne, 2003).

$\mathrm{Bu}$ ayırım kendisini mevcut literatürde de göstermektedir. Hajizada ve Marziacq (2013)bölgeyi aynı belirli coğrafi alanda konumlanan bir grup devletin karşılıklı bağımlılık ve coğrafi ilişkiler derecesine göre ilintilendirirken, Maior ve Matei (2005) Deutsch'un 1957 tarihli çalışmasındaki bölge tarifi uyarınca, paylaşılan stratejik değerler, ortak ilgi ve tehditler ve topluluk hissi olgularına vurgu yapmaktadır. King (2008) Deutsch'a katılmakla beraber ortak kimliğin olmazsa olmaz unsur olduğunu düşünmemektedir. Hatto ve Tomescu (2008) ise bölgenin sadece coğrafyaya dayandırılamayacağını, politika, ekonomi ve kültürle de ilintili olduğunu savunmaktadır.

Bunların yanında yeni bölgeselciliğin bölgeyi algılama metotları da farklıdır. Fawcett ve Hurell (1995) bölgesel örgütler ve bölgesel ekonomik yapılara vurgu yaparken, Adler ve Barnett (1998) Deutsch'un çalışmasından yola çıkarak güvenlik topluluklarını ortaya atmaktadır. Bu kavrama göre devletlerin barışçıl eğilim amacı güden güvenlik politikaları onları uluslararası düzeyde bir topluluk haline getirebilir (Adler ve Barnett, 1998). Bunlardan yola çıkarak yeni bölgeselciliğin devletlerden oluşmadığını, fakat bölgelerarası ekonomik, çevre, teknoloji ve iletişim ilişkilerinden oluşmaktadır yargısına varılabilir (Manoli, 2012).

Eski ve yeni bölgeselcilik kavramları göz önüne alındığında ise Karadeniz yine bazı tartışmaların odağında yer almaktadır. Çalışmaya başlamadan önce Karadeniz bölgesinin sınırlarının çizilmesinde fayda vardır. Amerika Birleşik Devletleri (ABD)-menşeli düşünce kuruluşları Geniş Karadeniz Bölgesi kavramını yayınlarında sıkça kullanırken (Cornell, Jonsson, Nilsson ve Haggström 2006; Hamilton ve Mangott, 2008), Karadeniz Ekonomik İşbirliği Teşkilatı (KEİT) Geniş Karadeniz Alanı (Triantaphyllou, 2009) kavramını kullanmaktadır. Bunda örgütün sadece Karadeniz'e kıyısı olan ülkeleri değil Arnavutluk ve Sırbistan gibi Karadeniz dışından ülkeleri üyesi olarak katmasının payı bulunmaktadır. Bu çalışmada ise Avrupa Birliği'nin (AB) sınırlarını çizdiği Karadeniz Bölgesi tanımı kullanılacaktır. Bunun nedeni AB'nin belli özellikleri göz önüne alarak bir bölge çizme eğiliminin olmasıdır. Avrupa Birliği Komisyonuna (COM [Comission of European Communities]) göre Karadeniz Bölgesi batıda Yunanistan, Bulgaristan, Romanya ve Moldova; kuzeyde Ukrayna ve Rusya; doğuda Gürcistan, Ermenistan ve Azerbaycan; ve güneyde Türkiye'yi içermektedir. Ermenistan, Azerbaycan, Moldova ve Yunanistan Karadeniz'e kıyısı olmayan ülkeler olsa da tarihi, yakınlığı ve yakın ilişkileri dolayısıyla bölgenin doğal aktörleri olarak tanımlanmaktadır (COM, 2007).

Karadeniz'in Soğuk Savaş sonrası kazandığı yeni kimlik literatürde farklı isimlerle anılmasına neden olmuştur. Bu yeni kimlikler daha ziyade bölgenin jeopolitik konumundan esinlenilerek yapılmış tanımlamalardır. Buna göre Karadeniz bölgesi için özgürlüğün sınırı (Asmus ve Jackson, 2004); bariyer ve köprü (Lesser, 2007; Simon, 2006); tampon bölge (Maior ve Matei, 2005), hub (Cornell vd, 2006) ve asıl kavşak (Rumer ve Simon, 2010) terimleri kullanılmaktadır. Bu farklı argümanların 
Karadeniz'in bir bölge olarak tanınması tartışmalarının bir sonucu olarak ortaya çıktığı yargısına varılabilir. Tartışmaların ortak görüşü ülkelerinin boyut, politik ve ekonomik, askeri potansiyeli, jeopolitik ilgiler ve kültürel, sosyal ve dini farklıkları Karadeniz bölgesini Avrupa'nın en heterojen ve karmaşı bölgesi yapmaktadır (Pavliuk, 2004). Bu nedenle de bölgeyi 'pasif coğrafi alan', 'kara delik' ve 'Avrupa entegrasyonunun yan etkisi' olarak adlandıranlar bulunmaktadır (Aydın, 2009).

Triantaphyllou (2009) bölgenin sorunlarını ve paradokslarını kabul etmekle birlikte yine de Karadeniz'i bölge olarak tanımlamaktadır. Yazar Karadeniz'i a priori (muhtemel) bölge olarak adlandırmaktadır. Manoli (2012) ise alt-bölge olarak tanımlamaktadır ancak tartıştığı alt-bölge kavramı bölge kavramıla benzerlikler sunmaktadır. Yazar 2010'daki yorumunda Karadeniz'in ne organik/doğal ne de objektif bir bölge olmadığını belirtmiş ve farklı heterojen unsurlara sahip ülkelerin sosyal etkileșimde bulunarak bir araya geldiğini ileri sürmüștür (Manoli, 2010). Bu yorumuyla inşacı bir yaklaşım sergilemektedir. King (2008) bazı çekinceleri olsa da özellikle AvrupaAtlantik örgütleriyle entegrasyonun Karadeniz'i bölgeye dönüştüreceğini savunmaktadır. Burada yazarın bölgenin iki önemli aktörü olan Rusya ve Türkiye'yi göz ardı etmesi ise tartışmalıdır. Bu tespitler arasında belki de en doğru olanı Hajizada (2010) tarafından yapılan Karadeniz'in işbirliği ve rekabeti içinde barındıran karmaşık bir bölge olduğu yorumudur.

Bir başka önemli tartışma ise eski ve yeni bölgeselcilik kavramları göz önüne alınarak analiz yapılmasını reddetmekte ve bölge oluşumunu aktörlerin kafalarında yarattıkları bir tasarı olarak yorumlamaktadır. Karadeniz bu görüşe göre bir güvenlik kompleksi olarak görülmektedir. Ciută (2008) ilgili çalışmasında Karadeniz'in bir bölge olmadığını aksine bir güvenlik kompleksi olduğunu vurgulamaktadır. Buna göre özellikle Avrupa'nın güvenlik algıları Karadeniz'in bölge olarak anılmasının temel nedenidir. Argümanına dayanak olarak da bölgedeki çatışmaları ve güvenlik tehditlerini, özellikle enerjinin Avrupa'ya güvenli taşınması kaygılarını göstermektedir (Ciută 2008; Tassinari, 2011).

Görülmektedir ki mevcut literatürde Karadeniz farklı çalışma alanlarına ve teorilere imkân sunan bir bölge konumundadır. Her ne kadar Glebov (2009) bölgenin teorik açıdan ele alınmaya hazır olmadığını belirtse de, yukarıdaki literatür taramasından da anlaşılacağı üzere bölgenin karmaşık yapısı onun ele alınırken eklektik bir yaklaşımla yaklaşılması gerektiğine dair ipucu vermektedir. $\mathrm{Bu}$ da içerisinde hem realizmi hem de inşacılık teorilerini barındırmalıdır. Bunun nedeni böyle bir teorik yaklaşım çalışmaya geniş bir perspektif sunma imkânı sağlayacaktır. Bu çalışmanın amacı bu tartışmadan yola çıkarak bunu yapmaktır. Bu amaç doğrultusunda çalışmada ilk olarak bölgesel güvenlik teorisi açıklanacak ve sonrasında teoriden ilham alınarak Karadeniz bölgesi incelenecektir.

\section{Model: Bölgesel Güvenlik Kompleksi}

\section{Teori}

Bölgesel Güvenlik Kompleksi (BGK) Barry Buzan ve Ole Wæver'ın ortak çalışmalarıyla oluşturdukları teoridir. Daha öncesinde Buzan'ın bölgeyi çalışmanın odak noktasına koyan araştırmaları olsa da (1983) asıl ilgisini Soğuk Savaşın bitimiyle bu kavrama yoğunlaştığı görülmektedir. $\mathrm{Bu}$ yoğunlaşmanın nedeni özellikle Soğuk Savaşın ardından var olan iki kutuplu uluslararası sistemin yıkılmasıyla yeni yapının daha fazla bölgesel karakter kazanmasıydı (Buzan, Wæver ve De Wilde, 1998). Burada amaçları mevcut teorik güvenlik çalışmalarını bölge düzeyine indirip akademik boşluğu doldurmak ve bu sayede Soğuk Savaş sonrası uluslararası sistemin yapısını açıklamaktı. Buzan'a göre bölge (2012, s.22) "Coğrafi olarak kümelenerek alt-sistem oluşturan ulusal yapıları ve süreçleri açısından özgün olan devletlerin bağlı oldukları geniş uluslararası sistem veya topluluktan farklılaşmalarıdır. Bölge uluslararası (küresel) düzey ve birim (devlet) düzeyi arasında yer alan bir analiz düzeyidir."

Bununla bölgenin en az devlet ve küresel düzey kadar önemli olduğunu vurgulanmaktadır. 2003 yılında Buzan ve Wæver'ın birlikte kaleme aldıkları "Bölgeler ve Güçler: Uluslararası Güvenliğin Yapısı" adlı kitapta bölgeye geniş vurgu yapılmaktadır. Soğuk Savaş sonrası oluşan yeni sistemle güvenlik yapısı iki kutuplu düzenden tek kutuplu düzene geçilmiş ve bu sistemin içinde de 
bölgeler yer almaktadır (1+4+bölge) (Buzan ve Wæver, 2003). Süper güç olarak ABD görülürken, AB-Avrupa, Rusya, Çin ve Japonya büyük güçler olarak görülmüş ve ayrıca bölge de eklenmiştir.

Yazarlar özellikle BGK kavramı etrafında geçmişte önem verilmeyen bölge kavramını ele almışlardır. Bu yeni kavramın hem materyalist hem de inşacı yaklaşımlar içermesi onu Soğuk Savaş sonrası alanlara uygulanabilirliğini arttırmıştır. Materyalist anlamda neorealist yaklaşımlar olan gücün dağılımı ve sınırlı toprak/alan kullanırken; inşacı anlamda güvenlikleştirme ve dost düşman algısını kullanmışlardır.

1983’te “İnsan, Devlet ve Korku” kitabında Buzan'ın güvenlik kompleksi tanımı “öncelikli güvenlik ilgilerinin birbiriyle sıkı sıkıya bağlı bir grup devletin ulusal güvenlikleri birbirlerinden ayrı düşünülemez" (1983, s.106) iken 2003'te yeniden formülasyonunda "güvenlikleştirme ve güvenlikdışılaştırma ya da her ikisinin süreçleri birbirleriyle çok sıkı bağlı olan bir grup birimin, güvenlik sorunları birbirinden ayrı analiz edilemez ve birbirinden ayrı çözülemez" (Buzan ve Wæver, 2003, s.44) şeklindedir. Adamides ve Christou (2015) bu yeni formülasyonu şöyle açıklamaktadır: devletler yerini birimlere bırakmıştır ve odak, güvenlik ilgilerinden ziyade güvenlikleştirme süreçlerinin karşılıklı bağımlılığı yönünde değişmiştir. Bu bağımlılık, birimlerin oluşturduğu bölgeyi etraflarındaki diğer birimlerin oluşturduğu bölgelerden farklı kılmaktadır.

Bu kavramla temel olarak devletlerin ortak güvenlik tehditleri onları bir araya getirmekte ve bu birliktelik de onların bir kompleks kurmalarını ve işbirliği yapmalarını sağlamaktadır fikri savunulmaktadırlar. Bu komşular arası güvenlik etkileşimi fikrinin altında özellikle tehdidin uzaktan geleceğinden ziyade yakın çevreden geleceği inancı/algısı yatmaktadır. Birimleri bir araya getirerek BGK kurulmasını sağlayan değişkenler dörde ayrılır. Bunlar sınır (bir bölgesel güvenlik kompleksini komşu kompleksten ayırır); anarşik yapı (bölgesel güvenlik kompleksi iki ya da daha fazla otonom birimden oluşmalıdır); kutupluluk (birimler arasındaki güç dağılımını içerir); ve sosyal yapıdır (birimler arası dost ve düşman boyutlarını içerir) (Buzan ve Wæver, 2003). Bu kavramlardan birindeki herhangi bir değişim yeni bir BGK kurulmasına yol açmaktadır.

Yazarlar kitaplarının teorik kısmını oluşturduktan sonra ampirik kısmında, özellikle Soğuk Savaş sonrası için, Asya'dan Amerika'ya uzanan9bölge ve 2 proto-kompleksi bu unsurlar çerçevesinde incelemişlerdir. Bu incelemeyi yaparken öncelikli olarak kompleksi oluşturan devletlerin ulusal güvenlik hassasiyetlerini ele almakta (güçlü devlet - zayıf devlet), ikinci olarak bölgeyi oluşturan devletlerin birbirleri arasındaki ilişkilerini; üçüncü olarak diğer bölgelerle etkileşimlerini; ve son olarak küresel güçlerin (uluslararası sistem) bölgedeki rolünü incelemektedirler. Burada her düzeyin bağımsız olarak anlaşılması birbirleriyle etkileşimlerinin anlaşılması kadar önemlidir. 11 güvenlik kompleksini seçerken yazarlar hem BGK'ye örnek oluşturabilecek bölgeleri seçmiş, hem de BGK yoksunluğu olan veya kompleks oluşturamamış bölgelere vurgu yapmışlardır.

Güvenlikleştirme(-dışılaştırma) BGK oluşumunda bir diğer önemli husustur. İnşacı bir temele sahip olan kavram, güvenliği söz-edim (speech act) olarak görür. Güvenlikleştirme "bir konunun (göç ve terörizm vb) öznenin varlığına yönelik tehlike/tehdit olarak dillendirilmesiyle normal siyasi sürecin dışına taşınması ve olağanüstü güvenlik tedbirleriyle karşılanması durumudur" (Wæver, 1995, ss.5455). Bir başka ifadeyle güvenlikleştirme "Siyasi bir toplulukta bir şeyin değerli bir öznenin varlığına yönelik bir tehdit olarak kabul edilen ve bu tehdide karşı acil ve olağandışı önlemler alınması çağrısında bulunmayı sağlayan süjeler arası bir anlayışın inşa edildiği başarılı bir söz-edinimidir" (Akgül-Açıkmeşe, 2011, s.59; Buzan ve Wæver, 2003, s.491).

Güvenlikleştirme özellikle Kopenhag Okulu tarafindan ortaya atılan ve amacı klasik uluslararası ilişkiler teorilerinin güvenlik kapsamını genişletmek olan bir kavramdır. Buna göre, klasik askeri güvenlik kavramının eksikliğini savunan görüş özellikle Soğuk Savaş sonrası güvenlik tehdidinin sadece askeri sektörde değil, politik, iktisadi, çevre ve toplumsal sektörlerde de oluşmakta olduğunu savunmaktadır. Askeri sektör kuvvete dayalı ilişkileri incelerken; politik sektör otorite, yönetim statüsü ve tanıma ilişkileriyle; iktisadi sektör ticari, üretim, finans ilişkileri; toplumsal sektör kolektif kimlik ilişkilerini; ve çevre sektörü insan faaliyetleri ve gezegenin biyosferi ile ilgilidir 
(Buzan vd, 1998). Güvenliğin genişletilmesi şüphesiz kavramın uygulanabilirliğini kolaylaştırmıştır. Buradaki süreç bir problemin güvenlikleştirici aktör tarafından (genelde politik karar alıcılar) devletin varoluşuna tehdit olarak deklare edilmesi ve bunun önlenmesi için istisnai önlemler alması ve bunun halk tarafından onaylanmasıdır. Bundan hareketle, hükümetler bir meselenin güvenlik konusu olduğunu açıklar ve bu toplumca kabul edildiği anda konu güvenlikleştirilmiş olur (Wæver, 1995).

Güvenlik-dışılaştırma ise "konuların aciliyet halinden çıkarılması ve siyasi alanda normal görüşmeler sürecine taşınmasıdır" (Buzan vd., 1998, s.4). Diğer bir deyişle "Siyasi bir toplulukta bir şeyin değerli bir öznenin varlığına yönelik bir tehdit olarak kabul edilme durumunun gerilemesi veya durması ve bu sayede bu tehdide karşı acil ve olağandışı önlemler alınmasının azalması veya bitmesidir" (Buzan and Wæver 2003, s.489).

Güvenlikleştirmeyi politikleştirmenin en aşırı ucu olarak düşündüğümüzde ortaya çıkan şema

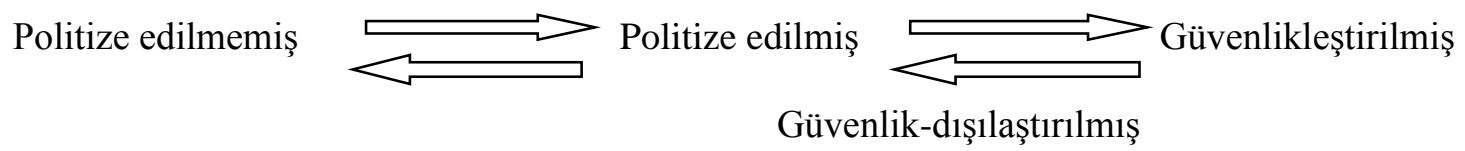

Ancak 2003 yılındaki kitapta Karadeniz diye bir bölgesel güvenlik kompleksi ele alınmamış aksine bölgeyi oluşturan devletler 3 farklı alt-komplekste incelenmiştir. İlki Avrupa güvenlik kompleksinin Balkan alt-kompleksi kısmında yer alan Yunanistan, Bulgaristan ve Romanya; Sovyetler güvenlik kompleksi kısmından yer alan bölgenin eski Sovyet ülkeleri - Azerbaycan, Ermenistan, Rusya, Ukrayna, Gürcistan ve Moldova, ve Türkiye izolatör ülke, komplekslerin arasında hiçbirine bağlı değil, olarak yer almaktadır. Bu nedenle de Karadeniz Bölgesi BGK uyarınca ele alınmamış ve de literatürde yeterince incelenmemiştir. Literatürdeki mevcut çalışmalarda Antonenko (2009) sadece bölgenin problemli yapısına vurgu yapmak için dost ve düşman ve coğrafi yakınlık değişkenlerini kullanmıştır. Ryabtsev (2006) bölgenin bir güvenlik kompleksi olmadığını çünkü Avrupa Güvenlik ve İşbirliği Teşkilatı (AGİT) gibi bir güvenlik örgütlenmesinin bulunmadığını ifade etmektedir. Ayrıca, ortak kimliğin, işbirliği yetersizliğinin ve bölge-dışı müdahalelerin kompleks kurmay1 engellendiğini savunmaktadır (Ryabtsev, 2006). Ciută (2008) ise Ryabtsev'in aksine mevcut güvenlik sorunlarının Karadeniz'i bir güvenlik kompleksi yaptığını belirtmektedir. Fenopetov, Lawlor, Japaridze, Tsantoulis, ve Schmid (2011) Karadeniz için pre-subcomplex (ön-altkompleks) ifadesini kullanmaktadır. İfadeye göre eğer birimlerin ikili güvenlik ilişkileri bunların bölgesel güvenlik kompleksi oluşturma potansiyelini gösterse de, birimler arasındaki yetersiz karşılıklı bağ bunun başarıya kavuşmamasına neden olmaktadır (Buzan ve Wæver, 2003). Buna göre Karadeniz'de ortak güvenlik hassasiyetleri vardır ancak karşı1ıklı güvenin çok güçlü olmaması bir BGK kurulması fikrinin ertelenmesine neden olmaktadır. Bu sorunlar aşıldığında Karadeniz de bir BGK olabilecektir. Bu da bölgesel örgüt yapısının geliştirilmesiyle oluşabilir. Bir başka görüş ise ortak güvenlik sorunları ve bölgesel çıkarların yakın olması Karadeniz'in BGK olarak kabul edilmesini güçlendirmektedir fikrini savunmaktadır (Asmus ve Jakson, 2004; Maior ve Matei, 2005). Bu nedenle de ortak güvenlik sorunları devletlerin birbirinden bağımsız olarak düşünemeyecekleri bir hal almıştır çünkü bir ülkenin güvenlik sorunu diğer bölge ülkelerini de otomatik olarak etkilemektedir ve bu da BGK oluşturma ihtiyacını arttırmaktadır.

$\mathrm{Bu}$ argümanlar ele alındığında ve aşağıda belirtilen ulusal güvenlik öncelikleri incelendiğinde bölgenin çatışmalı hali - dondurulmuş çatışmalar: Güney Osetya ve Abhazya Gürcistan'da; Dağl1k Karabă Azerbaycan ve Ermenistan arasında; Trans-Dinyester Moldova'da; Kuzey Kafkasya Rusya'da; ve Kırım Ukrayna ile Rusya arasında, ayrıca yasadışı göç, organize suçlar, ekonomik sorunlar ve genel olarak Karadeniz'in güvenliğini ilgilendiren (kaçakçılık ve kirlilik gibi) sorunlar BGK kurma ihtimalini ve böyle anılmasını arttırmaktadır. Çünkü bunlar ve benzeri güvenlik tehdidi unsurları devletlerarasındaki bağımlılı̆̆ - her ne kadar bölge devletleri bazı durumlarda birbirinden tehdit algılıyor olsa da - ve dolayısıyla da işbirliğini güçlendiren unsurlar olarak ortaya çıkmaktadır. Bu da Buzan ve Wæver'in BGK oluştururken göz önünde bulundurduğu ilkelerle bağdaşlaşmaktadır. $\mathrm{Bu}$ nedenle de Karadeniz bölgesinin bir BGK olma olasılığı bulunmaktadır. Bu bağlamda da BGK kavramı genişletilebilir. 


\section{Karadeniz BGK}

Yukarda belirtildiği gibi bölge ülkeleri üç farklı komplekste ele alınmıştır. Ulusal güvenlik hassasiyetlerinin ele alınacağı bu bölümde, amaç bölgeyi oluşturan ülkelerin bir kompleks oluşturabilecek ortak sorunlarını orta koymaktır.

İlk olarak Sovyet kompleksi ele alındığında ülkeler farklı alt komplekslerde yer almaktadır. Bunlar Ermenistan, Azerbaycan ve Gürcistan'dan oluşan Kafkasya mini kompleksi, Rusya ve Batı grubu (Ukrayna ve Moldova) olarak ele alınabilir. Rusya büyük güç olarak adlandırılırken, Kafkasya mini kompleksi izolatör olarak kabul edilmektedir (Buzan ve Wæver, 2003).Bu ülkelere bakıldığında ortak özelliklerinin Sovyetlerin dağılmasından sonra ekonomik, siyasi ve güvenlik sorunları yaşamalarıdır. Özele indirgemek gerekirse, bunlar dış müdahale, köklü yolsuzluk, sorumsuz politik elitler, millet ve devlet inşasında sorunlar, etnik ihtilaf ve yetersiz reformlardır (King, 2008). Sovyetler döneminden ve belki daha öncesinden beri bekleyen özellikle etnik temele dayanan sorunlar, dağılmayla gün yüzüne çıkmış ve hem devletlerin ulusal siyasi ve ekonomik olarak gelişmelerini engellenmiş hem de komşu ile yaşanan sorunlar dış politikada ülkeleri bölge dışı arayışlara yöneltmiştir.

Ülkeler temel alındığında; Gürcistan'da farklı etnik grupların yaşadıkları bölgeler olan Güney Osetya ve Abhazya bağımsızlıktan sonra kendi bağımsızlıklarını kazanma adına ayrılıkçı harekette bulunmuşlardır. Bu girişimleri Gürcistan özellikle Rusya'nın yardımıyla bastırabilmiş ancak bu Rus askeri gücünün bölgede konuşlanmasına yol açmıştır. Gürcistan'da 2003'te meydana gelen Kadife Devrimle ülkenin Rusya'dan ayrılan politik anlayışı ayrılıkçı hareketlerin canlanmasına ve bunların Rusya'dan destek bulmasına yol açmıştır. Sonunda da 2008'de Rusya ve Gürcistan'1 karşı karşıya getirmiştir. Mevcut durumda bu ayrılıkçı hareketler sözde bağımsızlıklarını ilan etseler de uluslararası toplum tarafından tanınmamaktadırlar. Gürcistan özellikle Rusya ile yaşadığı sorunlar ve bünyesinde barındırdığı ayrılıkçı yapılanma nedeniyle güvenlik tedarikçisi olarak Kuzey Atlantik İttifakı'nı (NATO) ve dolayısıyla Batı bloğunu görmektedir. Bu bağlamda öncelikli dış politika ve güvenlik hedefi NATO'ya üye olmaktır.

Ermenistan ve Azerbaycan arasındaki Dağglı Karabağ sorunu bir diğer dondurulmuş çatışma olarak bölgesel güvenliğe tehdit konumundadır. Yanlı Sovyet dönemi iskân politikası bölgedeki Azeri çoğunluğun Ermenilere kaptırılmasıyla sonuçlanmış ve Azerbaycan'ın bağımsızlığını ilan etmesiyle bölge Ermenistan'a katılma yönünde ayrılıkçı harekette bulunmuştur. Bu durum iki ülkeyi savaşa sürüklemiştir. Savaş 1992yılında patlak vermiş ve tarafları uzlaşmaya çağıran AGíT Minsk süreci de başarısızlığa uğramıştır. Dağlık Karabağ sorunu iki ülkenin dış politika ve güvenlik algıları üzerinde oldukça etkilidir. Özellikle güvenlik tedarikçisi ülke bulma konusunda iki ülke iki güçlü bölge ülkesini karşı karşıya getirmektedir. Rusya Ermenistan'ın güvenlik tedarikçisi olurken (hatta Rusya'nın ülkede askeri üssü bulunmaktadır - Gyumri), Azerbaycan'ın ki Türkiye ve dolayısıyla Avrupa-Atlantik bloktur. Azerbaycan'ın buradaki avantajı zengin doğal gaz kaynaklarına sahip olmasıdır, bu da kendisinin diğer eski Sovyet ülkelerine nazaran daha bağımsız bir dış politika izlemesini sağlamaktadır. Yine de özellikle askeri açıdan Rusya ile de işbirliği vardır. Etrafı Türkiye ve Azerbaycan tarafından çevrelenen Ermenistan ise hem askeri hem de siyasi olarak Rusya'ya bağımlı durumdadır. Dönem dönem iki ülke arasında çatışmalar meydana gelmektedir. Bunun sonuncusu ve belki de en önemlisi 2016 yılının Nisan ayında yaşanan çatışmalardır. Çatışma 4 gün sürmüş ancak bu 1994 'teki kısmı ateşkesten sonra yaşanan ilk ciddi çatışmasıdır. Bu bile düşman kavramının ve çatışma potansiyelinin ne kadar etkin ve güçlü olduğunu göstermektedir.

Moldova'daki Trans-Dinyester sorunu Moldova ile bölgedeki etnik çoğunluk olmaları nedeniyle Rusya ve Ukrayna arasındadır. Diğer dondurulmuş çatışmalara nazaran daha pasif olsa da yer yer sorunlar ortaya çıkmaktadır.Bu karşılıklı sorunların en günceli ve belki de en etkin olanı Rusya ve Ukrayna arasındaki Kırım, Sivastopol'daki Rus askeri üssü ve Ukrayna'da Rusların yoğunluklu olarak yaşadıkları Donetsk ve Lugansk (Donbas) bölgesi sorunlarıdır. Ukrayna'nın özellikle 2004 Turuncu devrimle iç ve dış politikada Rusya'dan ayrılması ve yönünü Batı'ya yöneltmesi iki ülke arasındaki gerginliği tırmandırmıştır. Bunun en büyük patlama noktası da 2014'te Rusya'nın Kırım'1 ilhakı ile sonuçlanmıştır. İlhak bölgede mevcut askeri yapılanma nedeniyle sadece Ukrayna'yı değil 
tüm Karadeniz ülkelerini de ilgilendirmektedir. Çünkü Rusya Karadeniz'de çok önemli bir üs elde etmiş ve askeri dengeyi tamamen kendi lehine çevirmiştir (Erşen ve Dal, 2018).

Bu ülkelerin ulusal politikadaki güvenlik hassasiyetleri göz önüne alındığında Rusya'nın özellikle potansiyel komplekslerin oluşmasında önemli bir yeri vardır. Ülkelerin Rusya'dan tehdit algılamaları (Ermenistan hariç) karşılıklı güvenlik bağlarını arttırmaktadır. Özellikle bunu mevcut ülkelerin Sovyetlerin dağılmasının ardından oluşturulan Bağımsız Devletler Topluluğundaki (BDT) tutumlarında görmekteyiz. Her ne kadar başlangıçta eski Sovyetler Birliği ülkelerinin hepsi örgüte üye olsa da Ermenistan ve Rusya hariç diğer bölge ülkeleri örgütün politik ve askeri kanatlarından ayrılmışlardır. Bu hareketle ayrılan ülkeler için en önemli güvenlik tedarik edici yapılar ABD ve AB olmuştur. Özellikle Rusya'yı dengelemek bakımından NATO ve AB'ye üye olmak ülkelerin öncelikli tercihleri arasındadır. Bunlar göz önüne alındığında ülkelerin karşılıklı güvenlik bağımlılıklarını artıran unsurun (Rusya) kompleks içerisinde yer alması bölgeyi daha da enteresan hale getirmektedir.

Rusya bu durumda hem kompleksin devamını savunurken hem de dağılmasını sağlayacak ya da başka bölgesel güvenlik komplekslerinin kurulmasına neden olabilecek ülke konumundadır. Bu durum kendisinin bölgenin en önemli güçlerinden biri olduğunu göstermektedir. Rusya'nın ulusal güvenlik hassasiyetlerine bakıldığında ise özellikle Sovyetlerin dağılmasını ardından yaşadığı ekonomik ve politik krizler örnek verilebilir. Buna ilave olarak Çeçenistan ve diğer Kuzey Kafkasya'da yaşanan ayrilıkçı hareketler güvenliğine önemli tehdit oluşturmuştur (Snetkov, 2015). Bu dönemde ulusal güvenlik daha ziyade güvenlikleştirilmiştir (Lo, 2003). Putin'in devlet başkanlığına geldiği 2000'den itibaren ise sorunların çözümünde yaşanan olumlu gelişmeler güvenlik hedefinin bir daha eski duruma dönülmemesi olarak değişmiştir (Snetkov, 2015). Rusya'nın temel güvenlik amacı özellikle eski Sovyet cumhuriyetleri üzerindeki siyasi, askeri ve ekonomik egemenliğini korumak ${ }^{1}$ ve bölgeye yabancı aktörlerin egemen olmasını önlemektir (Nalbandov, 2016). Özellikle ABD ve AB'nin bölgeye yönelik politikaları Moskova için en büyük tehditlerdir. NATO'nun Türkiye'nin yanı sıra Bulgaristan ve Romanya'daki askeri varlığı, Ukrayna ve Gürcistan'da yaşanan renkli devrimler bu yargıyı güçlendirmektedir. Rusya bunlara karşılık olarak bölge ülkelerindeki ayrılıkçı hareketleri desteklemektedir. Bu nedenle denebilir ki Rusya'nın bölge politikası güvenlik çerçevelidir.

İkinci olarak, Avrupa'nın Balkan alt kompleksinde yer alan Yunanistan, Bulgaristan ve Romanya hem NATO hem de AB üyesi olmaları bakımından önemlidirler çünkü güvenlikleri AvrupaAtlantik blok tarafından sağlanmaktadır. Bu devletlerin mevcut üyelikleri ayrıca bölge dışı aktörlerin ve örgütlerin sınırlarını ve ilgilerini Karadeniz'e taşımıştır. İlgili devletlerin ulusal güvenlik hassasiyetleri diğer bölge ülkelerine kıyasla nispeten daha azdır. Genel olarak Karadeniz'i hedef alan sorunlar kaçakçılık, çevre konuları ve taşıma gibi sorunlar bu ülkeler tarafindan dile getirilmektedir.

Son olarak Türkiye'nin ulusal güvenlik hassasiyetleri olarak özellikle 1990larda etkili olan Kürt sorunu ve laikliğe ve Kemalist rejime gelebilecek tehditler olarak gösterilebilir (Bilgin, 2008; Oğuzlu, 2007). Güvenlik tedarikçisi olarak görülen Batı/NATO özellikle Soğuk Savaş döneminde oldukça etkiliydi. Türkiye'nin AB'ye üye olma niyetlerinden biri de güvenlik hassasiyeti olarak görülebilir (Oğuzlu, 2007). Karadeniz'e kıyısı olan tek Sovyet boyunduruğu altında olmayan ülke olması bakımından Batı'nın da önceliklerinden biri Türkiye'nin güvenliğinin sağlanmasıdır. 2000lerde özellikle Adalet ve Kalkınma Partisi'nin iktidara gelmesiyle ulusal güvenlik anlayışı da değişmiştir. Burada eskiden sorun olarak görünen bölgeler, Sovyetler ya da Orta Doğu gibi, artık sorun olmaktan çıkmış aksine ekonomik ve politik işbirliği yapılabilecek alanlar olarak görünmeye başlanmıştır (Hale, 2013). Bir başka deyişle önceden güvenlikleştirilen bölgeler artık işbirliğinin cazip olduğu alanlara dönüşmüştür. Bu bağlamda Türkiye Rusya, Suriye ve hatta Ermenistan ile ilişkilerini geliştirmiştir (Aras ve Polat, 2008). Ancak Suriye ve Ermenistan ile olan ilişkiler hedeflenen düzelmeyi sağlayamamıştır. Özellikle 2011 yılında patlak veren Arap Baharı'nın yansıması olan ulusal çalkantılar Suriye'de de ortaya çıkmış ve ülke halen bir iç savaş içerisindedir. Türkiye'nin en uzun

\footnotetext{
1 Bunu ilk dönemde Bağımsız Devletler Topluluğu ve "Yakın Çevre" politikalarıyla yapmıştır. Bu yapıların amacı Sovyetlerin dağılmasıyla bağımsızlığını kazanan devletler ile Rusya'nın bağlarını koparmamak, politik, ekonomik ve askeri açıdan ilişkileri devam ettirmektir.
} 
kara sınırını paylaştığı ülke olması nedeniyle ülkenin içinde bulunduğu iç savaş ortamı Türkiye için de önemli bir ulusal güvenlik sorunu haline gelmiştir. Bu bağlamda Türkiye sınır güvenliğini koruma adına Suriye'nin kuzeyine askeri operasyonlar düzenleyerek hem en önemli sorun olarak gördüğü terörist unsurlardan bölgeyi temizleme hem de kendi güvenliğini koruma amacındadır.

Burada asıl tartışılması gereken konu Türkiye'nin gerçekten izolatör olup olmadı̆̆ıdır. Türkiye, Buzan ve Wæver'a (2003) göre 3 önemli bölgesel güvenlik kompleksini birbirinden ayırırken(Sovyet sonrası, Avrupa ve Orta Doğu), 4 önemli çatışma potansiyeli yüksek alt-güvenlik komplekslerine komşudur (Balkanlar, Kafkasya, Levant ve Körfez). Yazarlar Türkiye'nin bölgesel güç olma niyetinin olduğunu ancak bunu başaramadıklarını savunmaktadır. Çünkü farklı komplekslere ait ülkeleri bir araya getiremediklerini ifade etmektedirler, Yunanistan, Suriye ve Rusya gibi. Bu tabir mevcut literatürde çokça tartışılmış ve akademik çevre bunun özellikle son y1llarda Ak Parti iktidarının dış politika söylemleriyle geçerliliğini yitirdiğine vurgu yapmaktadırlar (Barrinha, 2013; Diez, 2005). Özellikle Türkiye'nin Karadeniz bölgesindeki siyasi tutumu kavramın yer yer doğruluğunu yer yer ise yanlışlığını ortaya koymaktadır. Karadeniz, diğer komşu bölgeler gibi, özellikle ülke içerisinde barındırdığı etnik kökeni bölgeye dayanan vatandaşları nedeniyle de önemlidir. Bunların güçlü varlıkları Ankara'nın bölgeye kayıtsız kalmasını engellemektedir çünkü olası bir sorun kendi ulusal güvenliğini de etkileyecektir (Oğuzlu, 2007). Türkiye'nin Karadeniz'deki öncelikleri bölgeye dış aktörlerin müdahalesinin önlenmesi ve Boğazlardaki egemenliğinin teminatı olan Montrö Boğazlar Sözleşmesinin korunmasıdır.

Ulusal güvenlik hassasiyetleri göz önüne alındığında bölge ülkelerinin ortak güvenlik sorunlarının olduğu söylenebilir. Bunlar ayrılıkçı hareketler, dondurulmuş çatışmalar, Rusya tehdidi, deniz güvenliği, ekonomik ve politik sorunlar olarak siralanabilir. Bu da bölge devletlerinin, her ne kadar birbirleriyle de sorun yaşasalar da, güvenliklerinin sağlanmasının birbirlerine bağlı olduğunu ve sorunların çözümünün birbirlerinden ayrı olarak ele alınamayacağını göstermektedir. Salt güvenlik kaygıları bu idealde belirleyici olmamış ekonomik ve politik sorunlar da Karadeniz'de kompleks oluşturma fikrini sıcak tutmuştur. Rusya ve Türkiye'nin durumu incelendiğinde ise Buzan ve Wæver (2003) Rusya'yı Soğuk Savaş döneminin iki süper gücünden biri ve bugünün büyük güçlerinden biri olarak görmüş ancak gücünü yitirdiği görüşünü savunmaktadırlar. Yukarıdaki örnekler göz önüne alındığında ise bu yargının geçerliğini kaybettiği görülmektedir. Bugün için Rusya süper güç imajına tekrar sahip olmaya aday ve mevcut düzende büyük güçtür. Türkiye ise izolatör ülke algısını yıkma çabasındadır ve bölgede yumuşak güç unsurları kullanımı buna örnektir.

\section{Karadeniz'de BGK Oluşumu Açısından Örgütsel Arayışlar}

Güvenlik hassasiyetleri ortak olan ülkelerin güvenlik kompleksi kurma eğilimlerinin yüksek olduğunu savunan BGK bu bölümde örgütler çerçevesinde incelenecektir. Bunun yapılmasının nedeni karşılıklı bağımlılıklarını artmasını sağlayan sorunların çözümü için atılan adımlar en iyi örgüt bünyesinde görülmektedir.

Haklı olarak ifade edilebilir ki Türkiye, Karadeniz'in bölge olarak anılması ve bölgeyi oluşturan ülkeleri bir araya getirme konusunda ilk ve etkin çalışmaları yapan ülke konumundadır. Türkiye bu bağlamda bölge ülkeleri arasında ortak güvenlik sorunları olarak görülen hem ekonomik örgütlenme ile hem de Karadeniz'in güvenliğini sağlayan örgütlenmeler ortaya koymuştur. Ekonomik örgütlenmeye örnek olan KEİT, deniz güvenliği ile ilgili Karadeniz Görev Gücü, Karadeniz Uyumu Harekâtı ve Karadeniz'e Sahildar Devletler Sınır/Sahil Güvenlik Teşkilatları İşbirliği Forumu (BSCF) hem bölgeselliğe hem de ortak sorun etrafinda bir güvenlik kompleksi kurulmasını sağlayacak atılımlar olarak örneklendirilebilir. Rusya'nın çalışmaları olsa da bunlar daha ziyade eski Sovyet bloğu ülkelerini bir arada tutmayı amaçlayan örgütlenmelerdir bu nedenle salt Karadeniz'i hedefleyen bir politikası yoktur. Türkiye bölge ülkelerini bir araya getirmeyi, karşılıklı diyalog kurulmasını, güveni arttırmayı amaçlayan ve bölgenin sorunlarının çözümü hedefleyen örgütsel çözümler ortaya koymuştur. Bu çözümler özellikle Batı-menşeli örgütlenmeler göz önüne alındığında daha etkilidir çünkü direkt bölge ülkelerinin sıkıntılarını göz önüne almaktadır. Ayrıca özellikle Rusya'nın desteğini de alması örgütlerin başarısını arttırmıştır. 
1992'de Türkiye'nin öncülüğünde Arnavutluk, Azerbaycan, Bulgaristan, Gürcistan, Ermenistan, Moldova, Romanya, Rusya, Ukrayna, Yunanistan'ın katılımıla kurulan KEIT, 2004'te Sırbistan'ın da katılımıyla on iki üyeye çıkmıştır. Aslında tarih boyunca ticaret ilişkileri bölge ülkelerini yakınlaştıran unsur olmuştur ve bu nedenle de Soğuk Savaş sonrası kurulan ilk işbirliği alanının ekonomiye dayanması tesadüf değildir (Manoli, 2010). Çoktaraflı politik, ekonomik atılımları bünyesinde barındıran örgütün amacı ekonomik işbirliği üzerinden bölgede özgürlüğü, istikrarı ve refahı canlandırmaktır (KEİT, 2015). Bir başka deyişle bölge güvenliği ekonomi üzerinden sağlanmaya çalışılmıştır. KEİT çok boyutlu bir örgüt olup işbirliği alanları ticaret ve yatırım, tarım, ulaşım ve iletişim, eğitim, organize suçlarla mücadele, enerji, turizm, çevre ve kültürdür (KEİT, 2015). $\mathrm{Bu}$ amaçlar doğrultusunda KEİT içerisinde çok farklı enstitüler barındırmaktadır. Bunlar: Uluslararası Sekreterlik; Proje Kalkındırma Fonu; Proje Uygulama Birimi; KEİT Parlamentosu; iş çevresinin gelişimini amaçlayan KEİT İş Konseyi; ticaret ve proje finansmanıyla ekonomik kalkınma ve bölgesel işbirliğini amaçlayan Karadeniz Ticaret ve Kalkınma Bankası; düşünce kuruluşu olarak Uluslararası Karadeniz Çalışmaları Merkezi; ve KEİT İstatistiki Data ve Ekonomik Bilgi Koordinasyon Merkezi (KEİT, 2015).

KEİT bazı ilkleri yaşatması bakımından önemlidir. Sovyetlerin dağılmasının ardından kurulan ilk örgüt olması bakımından yeni bağımsızlıklarını kazanan ülkeleri Rusya ile Rusya'nın kurucusu olmadığı bir (bölgesel) örgüt yapılanmasında bir araya getirmiştir. Örgüt ayrıca geçmişte ilişkilerin olmadığı Varşova Paktı ülkeleriyle NATO ülkelerini bir araya getirmiştir ${ }^{2}$. KEİT özellikle bölgedeki çatışmaları veya tarihten kalma sorunları olan ülkeleri, Türkiye-Yunanistan; Türkiye-Ermenistan; Azerbaycan-Ermenistan gibi, bir araya getirmesi bakımından da önemlidir. Ancak bu önyargılar örgütün bazı işleyişlerini zora sokmaktadır. Özellikle ülkelerin birbirleri arasında ticaretin geliştirilmesi amaçlamasına rağmen Azerbaycan-Ermenistan; Türkiye-Ermenistan; Rusya-Gürcistan ve Rusya-Ukrayna aralarındaki politik sorunlar nedeniyle kimilerinin arasında kısmen, kimilerinin ise tamamen ticaret yapılmamaktadır. Ayrıca KEİT toplantıları bu karşılıklı sorunların çokça dile getirildiği bir platforma dönüşmüştür. Örneğin Ermenistan ve Azerbaycan Dağlık Karabağ sorununu dile getirirken; Gürcistan ve Ukrayna Rusya ile olan sorunlarını dile getirmektedir. Ancak KEİT bunların çözümünde etkin bir rol oynayamamaktadır (Hajizada, 2014).

Türkiye'nin bir diğer önemli hamlesi de Karadeniz havzasının deniz güvenliğinin sağlanması adına 1998'de ön ayak olduğu "Karadeniz Görev Gücü” dür. 2001'de resmi anlaşmanın imzalandığ1 örgütün üyeleri Karadeniz'e kıyısı olan tüm ülkelerdir. Örgütün amacı terör tehdidinin ve Karadeniz'deki diğer risklerin azaltılması ve önlenmesidir (Hale, 2013). Örgüt arama ve kurtarma operasyonlarının yanı sıra, insani yardım ve çevre koruması da yapmaktadır. Ayrıca, Birleşmiş Milletler (BM) veya AGIT bünyesinde operasyonlara katılmaktadır (Hale, 2013). Rus-Gürcü Savaşından sonra etkinliğini korusa da, ki Gürcistan 2006'da üyeliğini askıya almış ve 2011'de tekrar katılmıştır, en son askeri tatbikatını 2013’te yapmıştır.

Karadeniz Uyumu Harekât1 2004 yılında yine Türkiye'nin girişimiyle kurulmuştur. NATO ve uzantısı Etkin Çaba Harekâtı ile benzerlik taşımaktadır ve Karadeniz havzasının en büyük güvenlik tedarikçisi olarak operasyonel deniz güvenliği üzerine yoğunlaşmaktadır. Amacı, BM Güvenlik Konseyi bünyesinde ortaya konan deniz sınırları kuralların korunmasını sağlamak; terör tehdidinin, yasadışı silah kaçakçılığını önlemektir. Türkiye bununla kıyıdaş ülkeler arasında barış ve güveni tesis etmek ve dış aktörlerin müdahalelerini engellemeyi amaçlamaktadır. Ayrıca Montreux Boğazlar Sözleşmesinin tartışmaya açılmasını önlemeyi de amaçlamaktadır. BGK lensiyle bakıldığında Karadeniz havzasında oluşabilecek tehditler kıyıdaş ülkeler için ortak olduğu için bu sorunların çözümü birbirinden bağımsız yapılamaz. Bu da onların bir kompleks içerisinde sorunlarının çözümünü sağlama adına bir araya getirmiştir. Ancak ülkelerin komşularına karşı var olan güvensizlik duygusunu engelleyememiştir. Özellikle Rusya'nın Kırım'ı ilhaklıyla da belirsiz hale gelmiştir (Germond, 2015). Yine de bu örgütler kıyıdaş ülkeleri bir araya getirme ve güvenliğin tartışılmasını sağlayan bir

\footnotetext{
2 Türkiye, Yunanistan ve Rusya gibi farklı komplekslere ait ülkeleri bir araya getirmesiyle Buzan ve Wæver'ın (2003) izolatör ülke tanımlamasına meydan okumuştur.
} 
platform olması bakımından önemli bir katkı yapmakta, en azından gelecekte olabilecek atılımlar için örnek teşkil etmektedir.

2000 yilında yine Türkiye'nin girişimiyle BSCF, Bulgaristan, Gürcistan, Romanya, Rusya ve Ukrayna'nın katılımıyla oluşturulmuş ve 2006 yılında kurumsallaşmıştır. Forumun görevleri arasında bölgedeki barış ve istikrarı sağlama, Karadeniz'de meydana gelebilecek kaçakçılık ve yasadışı faaliyetleri engellemek ve terörizm konusunda işbirliği ve de Karadeniz'in çevresel korunması bulunmaktadır (T.C Sahil Güvenlik Komutanlığı, 2019).

Bunlara ilave olarak Ukrayna'nın girişimiyle Gürcistan, Azerbaycan ve Moldova'nın oluşturduğu GUAM: Demokrasi ve Ekonomik Kalkınma Örgütü 1999'da NATO’nun 50.y1l zirvesinde resmen kurulmuştur. Örgütün amacı krizlerin ve çatışmaların çözümü, terörle mücadele, toprak bütünlüğü, egemenliğe saygı, devletlerin bağımsızlı̆̆1 ve uluslararası tanınırlığı olan sınırlarının korunmasidır (GUAM, 2015). Tsantoulis (2009) ise kurulma amacinın Rusya'nın dominant pozisyonunu dengelemek olduğunu savunmaktadır. Özellikle içerisinde etnik çatışmaların, ayrılıkçı hareketleri olan ve bunun dondurulmuş çatışmalara yol açmasına maruz kalan ülkelerden tarafindan oluşturulması GUAM'ın BGK tanımına da örnek oluşturan bir örgütlenme olduğunu göstermektedir. Bir başka değişle Buzan ve Wæver (2003) ortak bir tehdide yönelik tedbir alınması savı GUAM'ın kurulma nedenini BGK'nin sonucu olarak göstermektedir. Çünkü en önemli tehdit unsuru olan Rusya içerisinde yoktur. Ekonomik ve politik unsurların yanı sıra güvenliği sağlamayı da amaçlaması bir diğer örnek olarak gösterilebilir. Ancak, örgüt umulduğu kadar başarılı olamamış, aksine bazı üye ülkelerin Rusya ile ilişkilerini tamamen kesmek istememesi nedeniyle kâğıt üzerinde kalmıştır.

Ayrıca Yunanistan ve Romanya'da örgütsel yapılanmalar kurmuşlardır. Yunanistan özellikle KEİT içerisinde fazla etkinken, hatta bazı enstitülerin merkezi buradadır, Romanya demokratik örgütlerin kurulması için çaba sarf etmiştir. Demokratik Tercih Topluluğu (Community of Democratik Choice - CDC) ve Karadeniz Platformu son girişimler olarak örnek verilebilir. 2005 yllında Kiev'de kurulan CDC Baltık, Karadeniz ve Hazar Denizini kapsayan alandaki ülkeler arasında demokrasinin gelişimi, insan hakları ve hukukun üstünlüğünü amaçlamaktadır (Tsantoulis, 2009). Estonya, Gürcistan, Letonya, Lituanya, Makedonya, Moldova, Romanya, Slovenya ve Ukrayna üye ülkelerdir. $A B$ ve $A B D$ ise gözlemci statüdedir. 2006'da Romanya'nın öncülüğünde Azerbaycan, Bulgaristan, Ermenistan, Gürcistan, Moldova, Türkiye ve Yunanistan'ın katılımıyla Karadeniz Platform: Diyalog ve Ortaklık kurulmuştur. Platformun amacı bölgede ortak hedef yaratmak ve hükümetler-dışı hareket ederek bölgesel güvenliğin inşasında sivil toplum desteğini geliştirmektir (Tsantoulis, 2009).

Tüm örgütlerin amacı Karadeniz'de karş1lıklı güveni arttırma, bölgesel bağ yaratma ve silahlı çatışmaları azaltmadır. Bu nedenle de örgütsel atılımlar farklılıklar göstermektedir. Bunlara bakıldığında Karadeniz'deki örgütsel yapılanmalar üç unsurda toplanmaktadır. İlki KEİT ve GUAM'ın başı çektiği Soğuk Savaş sonrası bölge ülkelerinin tanınırlığını ve konumunu sağlamlaştırmayı amaçlayan bölgesel atılımlar; ikincisi CDC ve Karadeniz Platformu'nun başı çektiği belli bir sektörün gelişmesini amaçlayan sektörel atılımlar; ve sonuncusu aşağıda belirtilecek olan diştan (AB ve ABD) gelen atılımlardır (Manoli, 2010).

Son alarak 2008 yılındaki Rus-Gürcü savaşından sonra Türkiye'nin girişimiyle Kafkasya İstikrar ve İşbirliği Platformu kurulmaya çalış1lmıştır. Platform 1990larda yine Türkiye'nin girişimleriyle kurulmaya çalışılmış ancak başarısız olmuştur. Amacı barış ve güvenliği sağlamak ve dondurulmuş çatışmalara çözüm bulmaktı. Platform sınırlı bir alanı kapsasa da, Azerbaycan, Ermenistan, Gürcistan, Rusya ve Türkiye, barış ve istikrar hedefiyle bir güvenlik kompleksi kurmayı hedeflemekteydi. Ancak Gürcistan'ın savaş sonrası Rusya ile aynı platformda yer almak istememesi, Türkiye-Ermenistan yakınlaşmasına karşın Azerbaycan'ın çekimser kalması (Hale, 2013) nedenleriyle platform kurulmadan başarısızlığa uğramıştır. Ayrıca platformun bölge dışından İran ve AB'den destek almaması, aksine Rusya'nın ve Türkiye'nin egemenliklerinin pekiştiği bir yapı olarak görülmesi, dış destek unsurunu da kapatmıştır (Fotiou, 2009). Aslında güvenlik temelli bir örgütlenme olması bakımından eğer böyle bir örgütlenme olsa idi Karadeniz'in bir bölgesel güvenlik kompleksi olarak anılmasına katkı sağlayabilirdi ancak istenen olamamıştır. 
Bu yapılanmalar göz önüne alındığında her ne kadar bölge ülkeleri arasında pozitif etkisi olsa da örgütlerin ortak değer yaratma konusunda bazı sıkıntılar yaşadığı söylenebilir. Sıkıntıların nedenini Manoli (2010, s.337) şöyle sıralamaktadır: "Çözüme kavuşmayan çatışmaların devamı, liderler arasında siyasi sorumluluk ve güvenin inşası ihtiyacı, finansal ve kurumsal kaynakların azlı̆̆ı, özel sektör ve sivil toplumlun sisteme entegrasyonunun sağlanması ihtiyacı, ve bölgesel örgütlerin mevcut parçalanmış hali”.

Ayrıca Türkiye'nin kurdukları hariç, diğer örgütlerin Rusya'yı dışlamaları, aksine hedef almaları, Moskova tarafindan eleştirel karşılanmış ve tehdit unsuru olarak görülmüştür. Bu da örgütler içerisinde bölgeyi kapsamaları bakımından sorunlara neden olmuştur. Toparlamak gerekirse, Soğuk Savaşın bitimiyle bağımsızlıklarını yeni kazanan devletler, kendi egemenliklerini sağlama, uluslararası tanınırlıklarını kazanma ve de ekonomik, politik ve güvenlik sorunlarına çözüm bulma amacıyla mevcut sorunlarını bir kenara bırakarak diğer bölge ülkeleriyle ortak bir örgütsel yapılanma içersine girmişlerdir. Bu dönem nispeten güvenliğin dışsallaştı̆̆ (desecuritisation) dönem olarak görülebilir, ancak sorunlara çözüm bulunamaması, aksine tehdit unsurunun artması (2008 Rus-Gürcü Savaş1 ve Rusya'nın Kırım'1 ilhakı) ülkeler arasında güvensizliği arttırmış bu da dışsallaşan güvenliğin güvenlikleştirmeye dönüşmesine yol açmıştır. Bundan itibaren de bölgeselcilik çalışmaları önemini yitirmiş ve ülkeler arasında kurulması hedeflenen bağ zora girmiştir. Ancak yine de mevcut örgütler bölge ülkelerinin güvenliklerinin birbirlerinden ayrı olarak düşünülemeyeceğini ortaya koyan ortak sorunları göstermektedir. Ortak bir soruna karşı bir işbirliğinin yaratılması da uzun vadede hem bölgeselleşme hem de BGK oluşturma imkânı sunmaktadır.

Karadeniz bölgeselciliği denildiğinde sadece bölge ülkelerinin örgütsel atılımları yoktur, ayrıca daha öncede belirtildiği gibi bölge dışı aktörlerin özellikle kendi güvenliklerinin korunması adına yaptıkları örgütsel yapılanmalar da mevcuttur. Ülkelerin hepsi AGİT ve Avrupa Konseyine üye iken özellikle AB'nin Karadeniz'de özel girişimleri mevcuttur. Bunun nedeni olarak bölgeye yakınlığı ve özellikle Soğuk Savaşın bitimden sonra geçmişte uzak olan sorunlu bölgelere artık komşu olması verilebilir. 11 Eylül terör saldırısı, tehditlerin kendi sınırlarına ulaşabileceği kaygılarını daha da arttırmıştır. 2003 yılında $\mathrm{AB}$ tarafından kaleme alınan Avrupa Güvenlik Stratejisi üç temel üzerine oturtulmuştur. Terör, organize suçlar, çatışmaların önlenmesi ve yönetim sorunlarının çözümü için çalışma; uluslararası hukuk kurallarının devamının sağlanması; ve komşuların güvenliği (COM, 2003). $\mathrm{AB}$ böylece güvenlik sorunlarını tanımlamış ve olması gereken çözüm önerilerini getirmiştir. Komşularla ilgili olarak bu bağlamda onların toprak bütünlüklerine saygı ve iyi komşuluk ilişkilerinin geliştirilmesi hedeflenmiştir.

AB'nin bölge girişimleri 2007'de Bulgaristan ve Romanya'nın üyelikleri; Yunanistan'ın mevcut üyeliği; Türkiye ile üyelik müzakerelerinin yapılması; Rusya ise stratejik ortaklık ve bölge ülkelerini kapsayan Avrupa Komşuluk Politikası (ENP), Karadeniz Sinerjisi (BSS), ve Doğu Ortaklığıdır (EaP). ENP, AB tarafından komşularına sunduğu AB'nin politik, güvenlik, ekonomik ve kültürel işbirliği çerçevesinde çeşitli aktivitelerine katılmalarıdır (COM, 2004). Ancak bu aktivitelere katılmak AB üyeliği anlamına gelmemekte, sadece üye ülkeler ve komşular arasında "ring of friends" (iyi komşuluk) anlamına gelmektedir (Grant, 2011). Üye ülkeler Güney Akdeniz ve Kafkaslara geniş bir coğrafyaya uzanmaktadır. BSS, Almanya'nın dönem başkanlığında 2007 yılında ortaya konan bir oluşumdur. $\mathrm{AB}$ tarafindan kabul gören Karadeniz ülkelerinin hepsini içine alan oluşum bölge içerisinde işbirliğini, ayrıca $\mathrm{AB}$ ve KEİT ile de işbirliklerini arttırmayı amaçlamaktadır. Özellikle, mevcut devam eden enerji, güvenlik, çevre, ulaşım sorunlarını çözmeyi amaçlamaktadır (COM, 2007). $\mathrm{EaP}, \mathrm{AB}$ ve altı Doğu Avrupa ülkesini, Azerbaycan, Beyaz Rusya, Ermenistan, Gürcistan, Moldova ve Ukrayna, içine alan bir ortak girişimdir. EaP, hukukun üstünlügü, iyi yönetim, insan haklarına sayg1, azınlığın korunması, ve market ekonomisi ve sürdürülebilir kalkınma prensiplerini karşılıklı kurmaya dayanır (COM, 2008). Bu amaçlar doğrultusunda AB ile üye ülkeler arasında diyalogun geliştirilmesi, ülkelerin politik, ekonomik, hukuki sorunlarının çözümüne katkı sunmayı amaçlamaktadır.

ABD'nin Karadeniz politikaları ise demokrasinin tesisi, market reformu, enerji, güvenlik ve Larrabee'ye (2009) göre Rusya ile rekabete dayanır. ABD için Karadeniz'in Afganistan ve Irak gibi çatışmalı bölgelere yakınlığı, buraları kontrol altında tutmak ve olası gelebilecek terör tehditlerine 
karşı savunma sistemini kurmak, bölgeye olan ilgisini daha da arttırmıştır. ABD'nin lider konumda olduğu NATO'da Karadeniz bölgesine ilk vurgu 2004 NATO'nun İstanbul zirvesinde yapılmış ve bölgenin Avrupa-Atlantik güvenliği için önemi vurgulanmış ve bunun için üye ülkelerinin bölgenin güvenliği ve istikrarı için çaba göstermeleri gerektiği belirtilmiştir. Bunun da bölgesel işbirliği kurmakla olacağ ifade edilmiştir (NATO, 2004). NATO üyesi olmayan tüm ülkeler Barış Ortaklığı (Partnership for Peace - PfP) üyedir. Bunun yanında ABD, Ukrayna ve Gürcistan gibi ülkelerin NATO üyeliklerini desteklemiş, Romanya ve Bulgaristan'da 2004 yılında NATO'ya üye olmuşlardır.

Belirtmek gerekir ki bu örgütlerin temel amacı bölge sorunlarına çözüm bulmaktan ziyade $\mathrm{AB}$ ve ABD'nin kendi güvenliklerini koruma amacı taşıdığı için özellikle Türkiye'nin önderliğinde kurulan örgütler kadar başarılı olamamışlardır. Aslında bölgede barış ve güvenliğin tesisini amaçlayan $A B$ ve $A B D$, iki önemli bölgesel aktör olmaları bakımından Rusya ve Türkiye ile işbirliği yapmaları gerekirdi ancak işbirliği yapmak yerine rekabetçi bir tutum takınmayı tercih etmişlerdir. Bu rekabet bölge ülkelerini özellikle Batı ve Rusya arasında seçim yapmaya zorlamıştır. Ülkeler bir yandan Batılı kimliğe sahip olmak ve güvenliklerinin Batı tarafından sağlanmasını isterken, diğer yandan Rusya'nın müdahalelerine maruz kalmışlardır. Burada güvenlik tedarikçisi olarak AB ve NATO bünyesinde yer almayı seçen Ukrayna, Gürcistan ve diğer ülkeler ise, özellikle beklentilerinin - Rusya'ya karşı denge - karşılanmaması nedeniyle, hayal kırıklığına uğramışlardır. AB'nin sunduğu politikaların üyelik anlamına gelip gelmediği yönündeki karışıklığının giderilememesi ve AB'nin bölge ülkelerinin üyeliğine sıcak bakmaması aksine sadece iyi komşuluk ilişkilerini geliştirmek ve bu ülkeleri kendi standartlarına getirmek istemesi ve NATO'nun bölgede etkin olamaması bazı hayal kırıklı̆̆ unsurları olarak sayılabilir. Bu başarısızlık bu ülkeleri bölgede Rusya ile baş başa bırakmış ve bu da Rusya'nın bölgedeki büyük güç imajını güçlendirmiştir.

\section{Bulgular}

Karadeniz tam bir bölge halini alamamıştır ve halen yapım aşamasındadır. Bu bağlamda Aydın (2009) ve Tassinari (2011) bölgeyi haklı olarak sui generis (nevi şahsına münhasır) olarak nitelendirmektedirler. Yeni bölgeselcilik kavramı göz önüne alındı̆̆ında ise Karadeniz özellikle örgütsel yapılanmalar sayesinde bir bölge olarak oluşturulma çabası vardır. Bu örgütler politik diyalog sağlama, uluslararası platformda bölgesel sorunlara farkındalığı yükseltmeyi amaçlamaktadırlar ve bunu da özellikle ekonomik işbirlikleri ve deniz güvenliği temelli örgütlenmeler kurarak yapmaktadır.

Emerson (2008, s.255) Karadeniz'deki bölgeselciliği dokuz bölüme ayırmıştır: teknik, komşuluk, güvenlik, eklektik, örgütsel, işlevsiz, dönüşümsel, jeopolitik ve telafi edici. Bölgede aktörlerinin örgütsel ve politik çabaları göz önüne alındığında $A B$ ve NATO teoride örgütsel ve dönüşümsel bölgeselcilik kurmaya çalışırken, pratikte güvenlik bölgeselciliği kurmuştur. Türkiye ve Rusya ise örgütsel bölgeselciğin yanı sıra jeopolitik bölgeselcilik teknik ve iyi komşuluk bölgeselcilikleriyle kombine olmuş bir durumdadır. Bu farklı hedefler ise işlevsiz bölgeselciliğe neden olmuştur.

Bir unsur da Karadeniz'de bölgeselciliğin güvenlik konusuyla yakın ilişkili olduğudur. Bir diğer deyişle, hem bölge aktörlerinin hem de dış aktörlerin güvenlik hassasiyetleri Karadeniz'i bir güvenlik bölgesi yapmaktadır. Bölge ülkelerinin hassasiyetleri karşılıklı tehdit algısının varlığı, dost ve düşman ayrımının keskin oluşu ve zayıf ve güçlü devlet varlı̆̆ından ${ }^{3}$ kaynaklanan dengesizlik iken, dış unsurların güvenlik kaygıları olası bir çatışmanın coğrafi yakınlık nedeniyle kendilerine sıçraması ve özellikle enerjinin taşınmasında yaşanabilecek aksaklıklar olarak gösterilebilir (Antonenko, 2009; Tassinari, 2011). Bunlar da Karadeniz'de bir BGK oluşturma ihtimalini güçlendirmektedir.

Antonenko'ya (2009, ss.260-62) göre Karadeniz bölgesinde bir kompleks oluşmasını karmaşık hale getiren bazı faktörler vardır. Bunlar bölgenin coğrafyası ve tarihi: alan daha yeni bölge olarak ele

\footnotetext{
${ }^{3}$ Burada temel kavramlar olarak askeri güç kapasitesi, ekonomik refah seviyesi, ve politik gelişmişlik düzeyleri göz önüne alınmaktadır.
} 
alınmaya başlanmıştır ve bu yüzden yeni politik yapılaşma çok yavaş ilerlemektedir. Bunda politik, ekonomik, güvenlik ve tarihsel değerler önemli rol oynamaktadır. İkincisi dondurulmuş çatışmaların varlığı ve farklı bölge perspektifleri işbirliğini karmaşık hale getirmektedir. Üçüncüsü jeostratejik asimetri, bir yanda Türkiye ve Rusya gibi kendilerini bölgede varis gören güçlü devletler (eski imparatorluklar), diğer yanda söz sahibi olmaya çalışan Yunanistan, Romanya, Ukrayna ve Gürcistan gibi nispeten yeni ve Avrupa-Atlantik blok destekçisi ülkeler. Bu iki grup arasındaki denksizlik ortak görüşe varmayı engellemektedir.

Ancak özellikle güvenlik sorunlarının sınırları aşan bir yapısının olması ve bu durumun tüm bölge devletlerinin ortak sorunları haline gelmesi bir bölge ülkeleri arasında bir BGK kurma gereksinimini arttırmaktadır. Çünkü bölge ülkelerinin güvenlikleri birbirlerine bağımlı hale gelmekte ve sorunların çözümü sadece ulusal düzeyde mümkün olmamakta aksine bölgesel ya da küresel bir işbirliğine ihtiyaç duyulmaktadır. Daha önce belirtilen ekonomik, politik ve deniz güvenliğini önceliğine alan örgütlenmeler aslında belli bir soruna karşı bölge devletlerinin bir araya gelmeleri bakımından hem bölgeselcilik hem de BGK kurma bakımından önemli girişimlerdir. Bu bağlamda daha önce açıklanan KEİT, GUAM, Karadeniz Görev Gücü, Karadeniz Uyumu Harekâtı, BSCF, CDC ve Karadeniz Platformu'nun yanı sıra deniz kirliliğine karşı The Commission on the Protection of the Black Sea Against Pollution ve taşımacılığı ve ulaşımı daha güvenli sağlama amacıyla Black Sea Ring Highway gibi girişimlerde bulunulmuştur. Buradan da görüleceği üzere güvenlik sorunlarının çeşitlenmesi aslında Karadeniz bölgesini oluşturan ülkeler arasındaki işbirliği imkânını da arttırmaktadır. Ayrıca, ortak güvenlik sorunları sadece askeri güvenliği kapsamamak da ayrıca politik, ekonomik ve çevre güvenliklerini de öncelemektedir.

Buzan ve Wæver'ın (2003) “Bölgeler ve Güçler” kitabı göz önüne alındığında Karadeniz ile ilgili üç temel unsur görünmektedir. Bunlar mevcut dondurulmuş çatışmaların varlığg ve diğer ayrılıkçı hareketler ile bunların çözümü için atılan adımlar Wendt'in kategorisi ${ }^{4}$ göz önüne alındığında bölge güvenlik topluluğundan çatışma oluşumuna doğru ilerlerken; Rusya'nın büyük güç olduğu tek kutuplu bir yap1; ve Türkiye ve Kafkasya'nın izolatör olduğu bir komplekstir. Bu üçlüden güçlü olan unsur kompleksin de yapısını etkilemektedir. Bir başka deyişle bölgedeki çatışmaların devamı Ciută'ya (2008) göre bölgenin BGK olma ihtimalini arttırırken, çatışmalı ortamın iyileşmesi bölgeyi güvenlik topluluğu yapar; Rusya'nın tek büyük güç olması bölgeyi büyük güç BGK dönüştürür (Buzan ve Wæver, 2003). Ancak Rusya'nın bölgedeki gücünü kaybedip yerine bölge-dışı aktörlerin gelmesi kompleksi centred (merkezli) yapar. Son olarak Türkiye ve Kafkasların izolatör pozisyonlarının güçlenmesi bölgeleri birbirinden ayırmaya devam ederken; izolatör olmaktan çıkmaları bölgesel dinamiklerin yanı sıra bölge dışı faktörlerin ve aktörlerin güvenlik konusuna entegre olacaklarını gösterir.

Yukarıdaki bölge ülkelerinin güvenlik hassasiyetleri ve örgütsel yapılanmalar göz önüne alındığında, özetlemek gerekirse üç tanım içerisinde Rusya'nın gücü gelişmiştir ve bu da bölgeyi büyük güce dayalı bir kompleks yapmaya sevk eder (Buzan ve Wæver, 2003). Rusya'nın, büyük güç olarak, Karadeniz'in hem bölgeselleşmesinde hem de BGK olarak anılmasında önemli rol oynadığ1 görünmektedir. Buzan ve Wæver (2003) üç olası senaryonun BGK geliştirebileceğinden bahsetmektedir. Bunlar mevcut durumun devamı; kompleks içi değişim; ve dışarıdan değişimdir. Bu üç senaryo içerisinde Rusya'nın güç kullanmaktan çekinmeyen tutumu (Gürcistan ve Ukrayna'da görüldüğü üzere) ve $\mathrm{AB} / \mathrm{ABD}$ 'nin etkinsizlikleri nedeniyle olası bir değişimin kompleksin içerisinden gerçekleşmesi kuvvetle muhtemeldir. Bu nedenle de özellikle Rusya'nın son dönemdeki tavrı bölgeyi çatışma oluşumuna dönüştürmektedir. Türkiye'nin Rusya ile mevcut yakınlaşması, bölge güvenliğini de nispeten düzeltebilir. Çünkü Rusya'nın bölgede güvenebileceği bir ülkenin olması, kararlılığını azaltabilir. Türkiye burada kilit rol oynamaktadır.

\footnotetext{
${ }^{4}$ Wendt (1999) devletlerarası ilişkileri üç kategoride toplamıştır: güvenlik topluluğu (barışçı); güvenlik rejimi (rekabete dayalı); ve güvenlik oluşumu (çatışmalı). Bu kategoriler devletlerin karşısındaki devleti nasıl algıladığına bağlı olarak oluşmaktadır.
} 
Glebov (2009) Soğuk Savaşın bitiminin ilk yıllarında bölgenin güvenlik kompleksi gruplaşmasını Rusya-Ermenistan-Yunanistan ve Batı bloğu tarafından desteklenen TürkiyeAzerbaycan-Gürcistan-Ukrayna-Moldova şeklinde göstermiştir. Romanya ve Bulgaristan'da Batı bloğu ile olan ilişkilileri nedeniyle son grup içerisinde yer almaktadır. Bu tabir bugün içinde geçerliliğini korumaktadır. Şunu da belirtmek gerekir ki Türkiye-Rusya ilişkilerinin kötü seyretmesi bu ayrımı belirginleştirirken, yakınlaşması gruplaşmanın etkinliğini zayıflatmaktadır. Örnek olarak 2015 Kasım ayında Türkiye ve Rusya arasında yaşanan Rus SU-24 savaş uçağının Türkiye tarafından düşürülmesi verilebilir. Krizden sonra gerginleşen ilişkiler neticesinde Türkiye Karadeniz güvenliğine çok önem vermiş ve bunu NATO bünyesinde hayata geçirmiştir. Bu bağlamda Mayıs 2016 NATO'nun Varşova zirvesinde Romanya'nın NATO'nun Karadeniz'de daimi bir askeri güç oluşturulması önerisini desteklemiştir (Erşen ve Dal, 2018). Bu adım özellikle Rusya ve Türkiye'nin NATO'nun Karadeniz'e yerleşmesini önlemeyi amaçlayan politikalarına da ters bir harekettir. Türkiye ayrıca Ukrayna ile stratejik ilişsilerini geliştirmiş ve bu manada Şubat 2016'da ortak askeri araç ve silah üretimi konusunda anlaşma imzalanmıştır. Bu anlaşmayı Mart'ta iki ülkenin Karadeniz'de ortak tatbikatı izlemiştir (Erşen ve Dal, 2018). Rusya ile ilişkilerin düzene girmesiyle de Türkiye'nin Karadeniz'deki hassasiyetini dile getirme durumu azalmış ve gruplaşma nispeten önemini kaybetmiştir.

Olası bir kompleks incelendiğinde, bölge ülkelerinin yanı sıra dört analiz düzeyine istinaden İran ve $\mathrm{AB} / \mathrm{Bat}$ Avrupa BGK bölgelerarası düzeyde kabul edilirken, $\mathrm{ABD} /$ Kuzey Amerika BGK küresel düzeyde ele alınmalıdır. ABD'nin süper güç olarak, $\mathrm{AB}$ ve Rusya'nın büyük güçler olarak varlıkları Karadeniz BGK süper kompleks yapmaktadır. Karadeniz, Avrupa içerisinde bir altkompleks olarak yer alabilir. Tarihsel olarak bakıldığında bu alt-kompleks Doğu ve Batı'yı birbirinden ayırdığı ve birbirleriyle iletişim kurmadıkları için bir izolatör olarak kabul edilebilir. Makarychev (2009) bu durumun bugün halen geçerli olduğunu belirtmekte ve Karadeniz'i Avrupa/AB ve Rusya/BDT arasında 'mini-izolatör kompleks' olarak görmektedir. Ancak Soğuk Savaş sonrası değişen düzen ve özellikle eski Sovyet Bloğuna üye bölge ülkelerinin (Romanya ve Bulgaristan) bugün AB/NATO içerisinde yer alması Karadeniz'in artık iki bloğu birbirine bağlayan bir köprü pozisyonuna sokmuştur. Ayrıca askeri tehdit yanında terör, organize suçlar, kaçakçılık gibi sınır aşan sorunların tehdit olarak algılanması Karadeniz'i önemli hale getirmiştir. Çünkü bu tehditler doğudan batıya doğru ilerleyebilmektedir.

Bir güvenlik örgütlenmesinin olmaması ortak güvenlik tehditlerinin anlaşılması bakımından durumu riskli hale getirse de Karadeniz'in özellikle Sovyetler Birliği'nin dağılmasından sonra ön plana çıkması ve öncesinde bölge ülkelerinin karşılıklı diyalogdan mahrum kalması ilerleyen dönemde özellikle mevcut örgütsel yapıların geliştirilmesiyle ve yeni yapılanmaların eklenmesiyle hem bölgeselleşmesi hem de BGK olması açısından önemli olacaktır. Burada en önemli husus ortak güvenlik sorunlarının ülkeler arasında karşılıklı bağımlılık oluşturması ve sorunların işbirliği harici bir yöntemle çözülemeyeceği inancıdır. Yine de belirtmek gerekir ki Karadeniz hem çatışmayı hem de işbirliğini içerisinde barındıran bir oluşum olduğu için bölgeselcilik ve BGK oluşum süreci diğer bölgelere nazaran farklı olduğu ve bu nedenle de sui generis olduğu savunulabilir.

\section{Sonuç, Tartışma ve Öneriler}

Soğuk Savaşın bitmesi uluslararası ilişkilerde kavram olarak devletlerin ve sistemin yanına bölgeyi de eklemiştir. Bununla özellikle hem daha önce değerlendirmeye alınmayan mevcut bölgeler ilgi odağına yerleşmiş, hem de belli bir temele oturtturulan - ekonomi, kültür ve güvenlik gibi - yeni bölgeler oluşturulmuştur. Bu bağlamda eski Sovyet coğrafyası farklı bölgelere ayrılarak akademinin ilgi odağı olmuştur. Karadeniz'in bölge olarak işlenmesi ve çalışmaların yapılması bu bağlamda sebeplendirilebilir. Bölgenin sıcak çatışma alanları olan Orta Doğu ve Kuzey Afrika'ya yakın olması ve NATO ve AB'nin güney komşusu olması onu hem bölgesel hem de küresel temelde önemli hale getirmiştir. Rusya kendini bölgenin halefi olarak görürken yakın çevresinde egemenliğini koruma hedefindedir; Türkiye Karadeniz'i kendi gölü olarak görmekte ve bölgesel güç kurmaya çalışmaktadır. Romanya ve Bulgaristan kendi politik egemen ve bağımsız enstitülerini kurma amacındadırlar. Yunanistan ise bölgedeki varlığını arttırma çabasındadır. Diğer bölge ülkeleri, Azerbaycan, 
Ermenistan, Gürcistan, Moldova ve Ukrayna, ise Rusya ve Batı çatışmasının arasında kalmış ve kendilerine yer aramaktadırlar. $\mathrm{Bu}$ arada $\mathrm{AB}$ ve NATO gibi Avrupa-Atlantik bloğu ise kendi güvenliklerini korumanın önceliğindedirler.

$\mathrm{Bu}$ farklılıklar 1şığında Karadeniz bölgesi hem güvenlik menşeli hem de politik menşeli algılamalar içerisinde yer alabileceğini göstermiştir. Karadeniz hem bir bölge olabilir algılar göz önüne alındığında; hem de bir BGK olabilir ortak sorunlar göz önüne alındığında. Bölge olarak ele alındığında özellikle bölgesel örgütlerin işlevlerinin artması bölge ülkeleri arasında diyalogu arttırma fırsatını sağlayacaktır. Ancak mevcut durumu da Karadeniz'i bölge olarak kabul etmemizde yeterlidir. Bir BGK olarak Karadeniz çatışma oluşumunun baskın olduğu ve Rusya'nın bölgesel büyük güç olduğu bir Avrupa alt-kompleksidir. Türkiye burada bir izolatör değil aksine hem bölgeselleşmeyi hem de güvenlik kompleksi kurulmasında etkin olan bölgesel güç konumundadır. Bölgenin çatışmalı durumunun devamı ve ortak güvenlik sorunları kompleksin varlığını daha da arttıracaktır. Heterojen ve siyasi anlamda karmaşı yapısı ve çatışma ve işbirliğinin iç içe olması Karadeniz'in sui generis bir bölge (Aydın, 2009; Tassinari, 2011) ve bölgesel güvenlik kompleksi olduğunu göstermektedir.

Yine de Hajizada'nin (2014) de belirttiği gibi bölge kurma uzun dönemli ve meşakkatli bir iştir. Burada devletlerarası politik, ekonomik tutumlar bölgenin geleceği için belirleyici olacaktır. Bu bağlamda özellikle bölgesel yapılanmaların çalışılması Karadeniz ve diğer Karadeniz gibi yapıya sahip bölgelerin anlaşılmasını sağlayacaktır. Bu yapı içerisinde bölge ülkeleri arasında diyalog fırsatlarının sadece politik alanda değil, ekonomik, güvenlik ve özellikle sosyal alanlarda gelişmesi sağlanmalıdır. $\mathrm{Bu}$ durum sadece siyasiler tarafından değil, sivil toplum örgütleri vasıtasıyla gerçekleştirilebilir. Ayrıca mevcut bölge örgütleri desteklenmeli ve dönemin güvenlik, politik ve ekonomik yapılarına uygun olarak geliştirilmelidir.

\section{Kaynaklar}

Adamides, C. and Christou, O. (2015).Beyond hegemony: Cyprus, energy securitisation and the emergence of new regional security complexes.in Litsas, S. and Tziampiris, A. (Eds), The Eastern Mediterranean in transition: Multipolarity, politics and power(p.179-190). Surrey: Ashgate.

Adler, E. and Barnett, M. (1998). Security communities in theoretical perspective. in Adler E. and Barnett, M. (Eds), Security communities (p.3-28). Cambridge: Cambridge University Press.

Akgül-Açıkmeşe, S. (2011).Alg1 mı, söylem mi? Kopenhag okulu ve yeni klasik gerçekçilikte güvenlik tehditleri.Uluslararası İlişkiler, 8(30), 43-73.

Antonenko, O. (2009). Towards a comprehensive regional security framework in the Black Sea region after the Russia-Georgia war, Southeast European and Black Sea Studies.9(3), 259-269.

Aras, B. and Polat, R. (2008). From conflict to cooperation: De-securitization of Turkey's relations with Syria and Iran.Security Dialogue.39(5), 495-515.

Asmus, R.D. and Jackson B.P. (2004).The Black Sea and the frontiers of freedom.inAsmus, R.D., Dimitrov, K. ve Forbrig, J. (Eds).A New Euro-Atlantic Strategy for the Black Sea region (p.1726). Washington: The German Marshall Fund of the United States.

Aybak, T. (2001). Introduction. inAybak, T. (Eds).Politics of the Black Sea: Dynamics of cooperation and conflict (p. 1-14). New York: I.B. Tauris \& Co Ltd.

Aydın, M. (2009). Geographical blessing versus geopolitical curse: great power security agendas for the Black Sea region and a Turkish alternative. Southeast European and Black Sea Studies. 9(3), 271-285. 
Barrinha, A. (2013). The Ambitious insulator: Revisiting Turkey's position in regional security complex theory.Mediterranean Politics. 2013, 1-18.

Bilgin, P. (2008). The securityness of secularism? The case of Turkey.Security Dialogue. 39(6), 593 614.

Buzan, B. (1983).People, states and fear: The National security problem in international relations. Brighton: Wheatsheaf Books Ltd.

Buzan, B., Wæver, O. and De Wilde, J. (1998).Security: A new framework for analysis. Boulder: Lynne Rienner.

Buzan, B. and Wæver, O. (2003).Regions and powers: The structure of international security. New York: Cambridge University Press.

Buzan, B. (2012).How regions were made, and the legacies for world politics: An English school reconnaissance.in Paul, T.V. (Eds), International relations and regional transformation (p.2246). Cambridge: Cambridge University Press.

Ciută, F. (2008). Region? Why region? Security, hermeneutics, and the making of the Black Sea region.Geopolitics, 13(1),120-147.

Commission of the European Communities. Communication from the Commission. European Neighbourhood Policy Strategy Paper. COM (2004) 373 final. Brüksel. 12/05/2004.

Commission of the European Communities. Communication from the Commission to the European Council and the European Parliament. Black Sea Synergy-A New Regional Cooperation Initiative. COM (2007) 160 final. Brüksel, 11/04/2007.

Commission of the European Communities. Communication from the Commission to the European Parliament and the Council. Eastern Partnership. COM (2008) 823 final. Brüksel, 3/12/2008.

Council of European Union (2003).European Security Strategy.Brüksel. 15895/03. 12.03.2017 tarihinde http://register.consilium.europa.eu/pdf/en/03/st15/st15849.en03.pdfadresinden erişilmiştir.

Cornell, S., Jonsson, A., Nilsson, N. and Haggström, P. (2006).The wider Black Sea region: An emerging hub in European security. Uppsala: Uppsala University.

Diez, T. (2005). Turkey, the European Union and security complexes revisited.Mediterranean Politics,10(2), 167-180.

Emerson, M. (2008).The EU's new Black Sea policy.in Hamilton, D. and Mangott, G. (Eds), The wider Black Sea region in the $21^{\text {th }}$ century: Strategic, economic and energy perspective (p.253-276). Washington, DC: Central for Transatlantic Relations.

Erşen. E. ve Dal, E.P. (2018). Türk-Rus ilişkilerinin Karadeniz-Kafkasya boyutu: Uçak krizi ve sonras1, Karadeniz ve Kafkaslar: Riskler ve Firsatlar.14.07.2019 tarihinde http://www.tasam.org/Files/Icerik/File/Pages_from_karadenizkafkaskong_pdf_24fdc87b8d1d-4a3a-a8cb-96e1c1a896a3.pdfadresinden erişilmiştir.

Fawcett, L. and Hurrell, A. (1995). Regionalism in world politics: Regional organization and international order. Oxford: Oxford University Press. 
Fenopetov, V., Lawlor, B., Japaridze, T., Tsantoulis, Y. and Schmid, A. (2011). New security threatsold security architecture and mind-sets: Countering the threat of radiological and nuclear terrorism in the Black Sea region.American Foreign Policy Interest: The Journal of National Committee on American Foreign Policy.33(5), 197-208.

Fotiou, E. (2009).Caucasus Stability and Cooperation Platform: What is at stake for regional cooperation.ICBSS Policy Brief, 16(June 2009), 1-22.

Germond, B. (2015).The Maritime dimension of European security: Seapower and the European Union. Palgrave Macmillan.

Glebov, S. (2009). Black Sea security as a regional concern for the Black Sea states and the global power.Southeast European and Black Sea Studies.9(3), 351-365.

Grant, C. (2011). A new neighbourhood policy for the EU.Centre for European Reform Policy Brief.March, 1-13.

GUAM (2015). About GUAM. 12.06.2018 tarihinde http://guam-organization.org/enadresinden erişilmiştir.

Hajizada, M. and Marciacq, F. (2013). New regionalism in Europe's Black Sea region: The EU, BSEC and changing practices of regionalism.East European Politics.29(3), 305-327.

Hajizada, M. (2014). Patterns of regional collaboration and institutional cooperation around the Black Sea. Perceptions. 19(3), 101-121.

Hale, W. (2013).Turkish foreign policy since 1774. Third Edition. Oxon: Routledge.

Hamilton, D. and Mangott, G. (Eds) (2008).The wider Black Sea region in the $21^{\text {th }}$ century: Strategic, economic and energy perspective. Washington: Central for Transatlantic Relations.

Hatto, R. and Tomescu, O. (2008). The EU and the wider Black Sea region: Challenges and policy options.Garnet Policy Brief.(5), 1-8.

Hettne, B. (2003).The new regionalism revisited.in Soderbaum, F.,and Shaw, T. (Eds).Theories of new regionalism (p.22-42).Basingstoke: Palgrave Macmillan.

KEİT, (2015). Point of reference for regional cooperation and understanding. 14.05.2017 tarihinde http://www.bsec-

organization.org/Downloads/Brochure\%202015\%20last\%20version\%20as\%20published\%20f or\%20the\%20website.pdfadresinden erişilmiştir.

King, C. (2008).The wider Black Sea region in the twenty-first century.in Hamilton, D. and Mangott, G. (Eds).The Wider Black Sea Region in the $21^{\text {th }}$ century: Strategic, economic and energy perspective (p.1-19). Washington: Central for Transatlantic Relations.

Larrabee, F.S. (2009). The United States and security in the Black Sea region.Southeast European and Black Sea Studies, 9(3), 301-315.

Lesser, I. (2007). Global trends, regional consequences: Wider strategic influences on the Black Sea. Xenophon Paper, 4(13).

Lo, B. (2003).Vladimir Putin and the evolution of Russian foreign policy. London: Chatham House.

Maior, G.C. and Matei, M. (2005). The Black Sea region in an enlarged Europe: changing patterns, changing politics. Mediterranean Quarterly. 16(1), 33-51. 
Makarychev, A. (2009). Russia's perspectives of Black Sea regionalism.Turkish Policy Quarterly.8(3), 60-72.

Manoli, P. (2010). Where is Black Sea regionalism heading?.Southeast European and Black Sea Studies.10(3),323-339.

Manoli, P. (2012).The Dynamics of Black Sea subregionalism. Surrey: Ashgate.

Nalbandov, R. (2016).Not by bread alone: Russian foreign policy under Putin. Potomac Books, Nebraska: Nebraska UP.

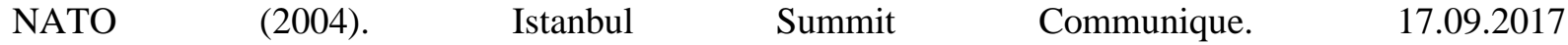
tarihindehttp://www.nato.int/docu/pr/2004/p04-096e.htmadresinden erişilmiştir.

Oğuzlu, T. (2007). Soft power in Turkish foreign policy. Australian Journal of international affairs.61(1),81-97.

Pavliuk, O. (2004).Introduction.in Pavliuk, O. and Klympush-Tsintsadze, I. (Eds).The Black Sea region: Cooperation and security building (p.3-12).New York: EastWest Institute (EWI).

Rumer, E.B. and Simon, J. (2010).Towards a Euro-Atlantic strategy for the Black Sea region.in Haro, F.W. (Eds) (2010).Georgia and the Caucasus region (p.17-40). New York: Nova Science Publishers, Inc.

Ryabtsev, V. (2006). Why is there no "security complex" in the Black Sea-Caucasus region. OSCE Yearbook 2006. 15.02.2017 tarihindehttps://ifsh.de/fileCORE/documents/yearbook/english/06/Ryabtsev-en.pdfadresinden erişilmiştir.

Simon, J. (2006).Black Sea regional security cooperation: Building bridges and barriers.inAsmus R.D. (Eds).Next steps in forging a Euroatlantic strategy for the wider Black Sea (p. 83-100). Washington: German Marshall Fund of the United States.

Snetkov, A. (2015). Russia's security policy under Putin: A Critical perspective. London: Routledge.

Soderbaum, F. (2016).Rethinking regionalism. London: Palgrave.

Tassinari, F. (2011). Region-building as trust-building: The EU's faltering involvement in the Black Sea region. Southeast European and Black Sea Studies. 11(3), 227-239.

Triantaphyllou, D. (2009). The 'security paradoxes' of the Black Sea region.Southeast European and Black Sea Studies.9(3), 225-241.

Tsantoulis, Y. (2009). Geopolitics, (sub)regionalism, discourse and a troubled 'power triangle' in the Black Sea. Southeast European and Black Sea Studies.9(3), 243-258.

Türkiye Cumhuriyeti Sahil Güvenlik Komutanlığı (2019). Karadeniz’e Sahildar Devletler Sınır/Sahil Güvenlik Teşkilatları İşbirliği Forumu (BSCF). 30.04.2020 tarihinde https://www.sg.gov.tr/karadenize-sahildar-devletler-sinirsahil-guvenlik-teskilatlari-isbirligiforumu-bscf adresinden erişilmiştir.

Wendt, A. (1999).Social theory of international politics. Cambridge: Cambridge University Press.

Wæver, O. (1995).Securitisation and desecuritisation.in Lipschutz, R.D (Eds).On Security (p.46-86). New York: Columbia UP. 


\section{Extended Abstract}

\section{Introduction}

The Black Sea Region (BSR) has become a new strategic frontier for regional and global actors in particular after the demise of the Soviet Union. This paves the way for studying the region as a research area. The basic discussion on the region is related to the acceptance of the Black Sea as a region or not. While one group has some doubts about its acceptance as a region and argue that it has constructed as a region, others accept it as a security complex.

\section{Theory}

\section{Model: Regional Security Complex (RSC)}

This study is inspired from Regional Security Complex Theory and place the BSR in this theoretical context. This section informs that the collaboration of Barry Buzan and Ole Wæver ensure putting regions in International Relations analysis. In this manner, the region has become as important as state and global levels. The theory argues that states perceive threat would have come from short distances rather than long ones. Thus, states, whose perceive the same threats, attempt to build security complexes towards the threat.

\section{BSR Regional Security Complex}

The national security vulnerabilities are stated in this section. It is argued that perceiving threat from neighbour and concerns on maritime security are security vulnerabilities of each country in the region. Thus, these common concerns pave the way for building RSC. However, it is argued that the authors of the theory did not consider the BSR as a RSC, but instead divided the region into three subcomplexes. Greece, Bulgaria and Romania are included within the Balkan sub-complex of Europe; Azerbaijan, Armenia, Moldova, Georgia, Ukraine and Russia are considered to be in the post-Soviet space; and Turkey is an insulator standing between regional security complexes where "larger regional security dynamics stand back to back" (Buzan and Wæver, 2003, p.490). Within this structure the BSR is located at the intersection of post-Soviet great power and Western great power influence.

\section{Organisational attempts in building RSC in the BSR}

Regional organisations are discussed in this section. Regional initiatives, in this manner, are important for sharing norms and forming a new regional identity in the BSR. With the involvement of both regional and non-regional powers following the demise of the Soviet Union, the BSR has witnessed a great transformation, as well as competing forms of regionalism between the West and Russia and Turkey. With the establishment of regional organisations, the aim was to fill the gap of communality through facilitating mutual trust, creating regional cohesion and rendering armed conflict impossible. In this manner, there are variety of projects, ranging from economic and naval cooperation, to the promotion of democracy, and recently conflict resolution. The first regionalist initiatives in the early 1990s focused on asserting the BSR's post-Cold War international standing, while later ones have been driven more by sectoral issues and external engagements, early in the current decade.

The Black Sea Economic Cooperation (BSEC), in particular, is the most effective organisation in the region when comparing with others. It is important since containing both conflicting sides and targeting economic development in each country via improving trade relations. Other regional and global initiatives (European Union (EU) and North Atlantic Treaty Organisation (NATO)) cause disappointment among countries in the region. 


\section{Result}

According to their Regions and Powers book, and the way Buzan and Wæver (2003) mention regional countries within it, the BSR has three distinctive features: the conflict-cooperation paradox among regional states serves to reinforce fundamental dynamics among the security community, such as those of conflict formation; one central RSC, which is Russia as a great power; and two insulator entities, which are Turkey and the Caucasus.

It is discussed that considering state vulnerabilities and organisational attempts, the BSR is a sui generis region and a security complex. This is because it includes both conflict and cooperation. The BSR is a great power security complex and the problematic nature of the region, frozen conflicts i.e., categorises it as one characterised by 'conflict formation'. Turkey's regional organisation initiatives in the BSR indicate that contrary to what Buzan and Wæver (2003) argue, it is not an insulator state. On the contrary, as one can see in BSEC, Turkey could bring different countries in different complexes such as Russia and Greece.

Furthermore, while the EU/Western Europe RSC (and one might add Iran as well) is accepted at an interregional level, the USA/North American RSC is accepted at the global level.

\section{Conclusion, Discussion and Recommendations}

The BSR has become important both regionally and globally after the collapse of the Soviet Union. The differences among countries in the region on the one hand make dialogues and act in common difficult, while on the other hand increasing tension ensure the acceptance of the region as a RSC. In this situation, regional countries need to diversify dialogue areas. 